\title{
HYBRID INORGANIC-ORGANIC ACID MATERIALS: CHARACTERIZATION AND CATALYTIC PERFORMANCE IN ETHYL tert-BUTYL ETHER SYNTHESIS
}

\author{
T.G. Serebrii *, N.V. Vlasenko, Yu.N. Kochkin, P.E. Strizhak \\ L.V. Pisarzhevsky Institute of Physical Chemistry of National Academy of Sciences of Ukraine \\ 31 Nauki Pr., Kyiv, 03039, Ukraine
}

\begin{abstract}
We present a study on physical-chemical properties of hybrid inorganic-organic acid materials and their catalytic performance in ethyl tert-butyl ether synthesis under both atmospheric and elevated pressure. Such materials are compositions of acid styrene-divinylbenzene copolymer and silica with various (1.5-9.2 wt. \%) polymer loadings (loaded resins LR). We have found that LR has better thermal stability compared to that of commercial sulfonic resins. Acidic properties of LR show that the acidity of polymer phase decreases with increasing of polymer loading. Catalytic tests show that under atmospheric pressure ethyl tert-butyl ether synthesis requires a higher acid capacity of LR than that under elevated pressure and proceeds with $100 \%$ of selectivity. Under pressure the side reaction of tert-butanol formation occurs and LR samples with higher polymer content $(\geq 6.9 \mathrm{wt} . \%)$ possess lower conversion but higher selectivity compared to LR with polymer content below $6.9 \mathrm{wt} \%$.
\end{abstract}

\section{INTRODUCTION}

Methyl tert-butyl ether (MTBE) is widely used in the production of lead-free high-octane motor fuels [1]. However, due to harmful effect on the environment, the application of MTBE is expected to be limited in the future [2]. Ethyl tert-butyl ether (ETBE) gives a perspective alternative to MTBE. It surpasses existing highoctane additives in operational properties [3]. Using bio-ethanol for ETBE synthesis is especially attractive [4]. Usually ETBE synthesis is carried out over different types of acidic ionexchange resins. Among them, Amberlyst 15 which is a polymer matrix of acid copolymer of styrene and divinylbenzene, is used in industry $[5,6]$.

Acidic ion-exchange resins are produced either as macroporous material or gel. Depending on the degree of cross-linking, macroporous acid resins have micropores $(0.5-$ $2.0 \mathrm{~nm})$ and macropores $(20-60 \mathrm{~nm})$. Therefore, they have catalytic activity even in nonpolar media when the polymeric matrix is not in swollen form. However, gel acid resins show catalytic activity only in polar media when they are swollen [7].

Acidic ion-exchange resins are characterized by high catalytic activity and selectivity having several disadvantages, as low mass-transfer characteristics and poor thermal stability limiting their application [7]. In addition, swelling resin granules cause technical difficulties in their practical application. Therefore, acid catalysts with improved performance are desirable. An improvement may be reached by using hybrid inorganic-organic hybrid acid catalysts which combine advantages of both components, acid polymer matrix and inorganic phase [8]. Particularly, we have shown recently that hybrid inorganic-organic acid materials with low polymer loading and commercial acid resins have comparable productivity in the ETBE synthesis under elevated pressure [9].

Here we present a study on properties of hybrid inorganic-organic acid materials and their catalytic performance in ETBE synthesis under both atmospheric and elevated pressure. For this purpose we prepared loaded acid ion-exchange resins (LR-loaded resins) by copolymerization of styrene-divinylbenzene in the presence of commercial silica gel with further sulfonation. LR were prepared with different polymer loadings (1.5-9.2 wt. \%). Their texture, thermal stability, and acidity were studied. Our study showed a relation between the morphological and acidic properties of synthesized materials and their catalytic performance for ETBE synthesis under both atmospheric and elevated pressure. 


\section{EXPERIMENTAL}

Catalysts preparation. Loaded acid ionexchange resins (LR series) were prepared by copolymerization of styrene-divinylbenzene in the presence of commercial large pore silica gel with further sulfonation of obtained styrenedivinylbenzene copolymer by concentrated sulfuric acid. The procedure of preparation was described in details previously [9]. Content of polymer phase in obtained catalysts was found in the rage of $1.5-9.2 \mathrm{wt} . \%$. For synthesized materials we used an abbreviation LR-X, where $\mathrm{X}$ gives the loading amount of acid poly(styrenedivinylbenzene) resins.

The content of sulfur in catalysts composition was determined using the inductively coupled plasma atomic emission spectroscopy ((ICP-AES). Single-point BET surface area of studied materials was obtained by nitrogen adsorption at $-196{ }^{\circ} \mathrm{C}$ using a Gazometer GKh-1 (Russia). Thermogramms of LP-X samples obtained using a derivatograph Q 1000, MOM in the temperature range $20-500{ }^{\circ} \mathrm{C}$, at heating rate $10 \% \mathrm{~min}$ in air.

Acıdity characterization. Acid properties of loaded resins were determined by QETD method (Quasi-Equilibrium ThermoDesorption) using a vacuum unit with quartz balances of the McBain type, measuring amount of $\mathrm{NH}_{3}$ sorption in quasi-equilibrium mode [9]. It gives stepwise ammonia thermal desorption under condition of reaching adsorption equilibrium at each temperature step. Total concentration of the acid sites (ammonia sorption capacity) was determined as a quantity of ammonia adsorbed on a sample surface, at $50^{\circ} \mathrm{C}$.

Catalytic studies. ETBE synthesis under atmospheric pressure. Experiments were carried out in a steel tubular reactor $(0.64 \mathrm{~cm}$ in diameter) with fixed bed of catalyst $(0.1 \mathrm{~g})$. Ethanol was supplied by a pump into the evaporator heated to $150^{\circ} \mathrm{C}$ and with helium flow ethanol was sent to the mixer where it mixed with the flow of isobutylene. The molar ratio of ethanol/iso-butylene was 0.17 with total flow rate of $113 \mathrm{~cm}^{3} / \mathrm{min}$. Chemical composition of the reactor outlet stream was determined using a gas chromatograph (Agilent) equipped with a FID detector and a FFAB \% 15 Chromosorb AW column. To eliminate condensation, all tubes connecting the evaporator to the reactor and reactor to the gas chromatograph were heated to $120^{\circ} \mathrm{C}$.
ETBE synthesis under elevated pressure. ETBE synthesis was studied in a flow reactor with fixed bed of catalyst at $1.0 \mathrm{MPa}$ in the temperature range of $80-160{ }^{\circ} \mathrm{C}$. Ethanol and iso-butylene were measured from standing under pressure $\cong 1.2 \mathrm{MPa}$ vessels and by the help of drop wise samplers and "Whitey" needles. Space velocity of carrier gas helium was regulated by a needle valve and controlled by a differential manometer. Temperature in the reactor was fixed and controlled by a controller/programmer type 812 "EUROTHERM" (Great Britain). The pressure in the reactor and in the vessels with ethanol and iso-butylene was controlled by model manometers.

Catalyst loading was $1.5 \mathrm{~cm}^{3}$, grain size $1-2 \mathrm{~mm}$. Molar ratio ethanol/iso-butylene was 1.5, LHSV $-1 \mathrm{~h}^{-1}$, carrier gas helium. Ethanol was used as azeotropic mixture of $\mathrm{C}_{2} \mathrm{H}_{5} \mathrm{OH}$ with 4.43 wt. $\% \mathrm{H}_{2} \mathrm{O}$. Reaction products were analyzed by a gas chromatograph Agat (Russia) equipped with Chromaton N-AW column with $10 \%$ Carbowax 600 (3 mm i.d., $2 \mathrm{~m}$ length) and with a thermal conductivity detector.

\section{RESULTS AND DISCUSSION}

Characterization of hybrid inorganicorganic acid materials. Composition. Using the synthesis procedure for LR-X we obtained hybrid inorganic-organic acid materials that contained up to $10 \mathrm{wt}$ \% of polymeric phase. Figure 1 gives a correspondence between the total content of styrene and divinylbenzene in initial mixture and polymer loading in obtained materials. These data illustrate that only $\sim 10 \%$ of polymer transfers into porous support at $25 \%$ content of $(\mathrm{St}+\mathrm{DVB})$ in initial solution.

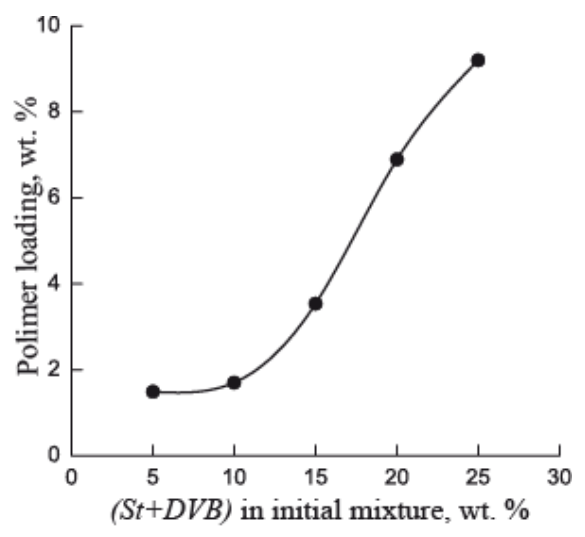

Fig. 1. Change of polymer loading with increase in $(\mathrm{St}+\mathrm{DVB})$ content in initial mixture 
Further sulfonation of obtained composite produces hybrid inorganic-organic acid materials. Figure 2 illustrates an effect of polymer loading on the sulfonation degree.

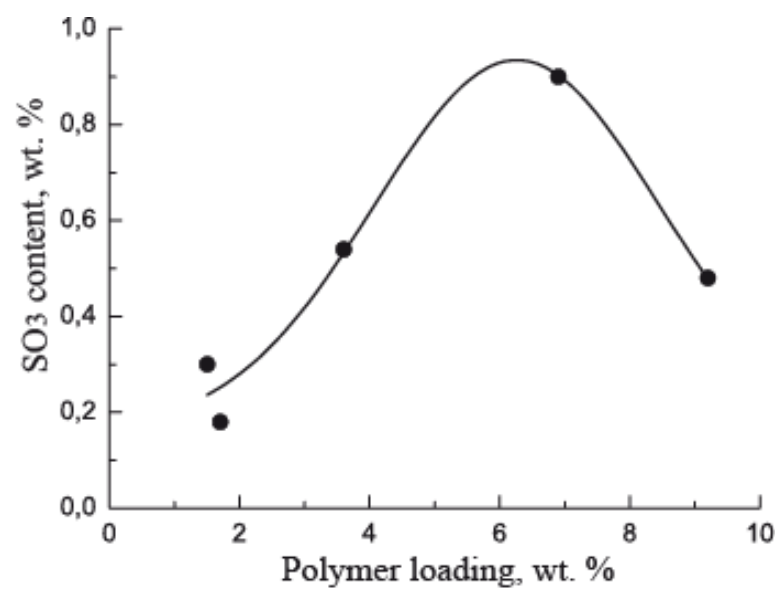

Fig. 2. Changes in the sulfur content (evaluate in $\mathrm{SO}_{3}$ ) with increase in polymer content
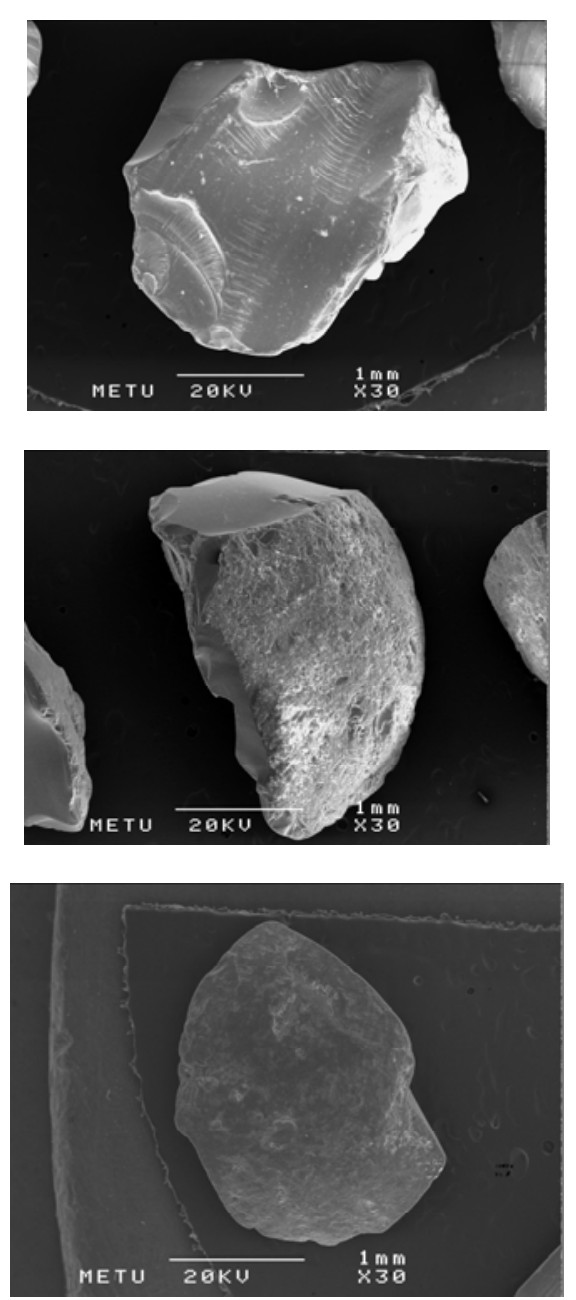

Increasing polymer loading up to $7 \mathrm{wt} . \%$ increases the content of sulfonic groups in the composite. The content of sulfonic groups decreases with further increase in the polymer phase content. Perhaps, this observation illustrates that only polymer surface is acidic whereas sulfonation does not follow deep inside the polymer phase. It is worth noting that decreasing content of sulfonic groups corresponds to increasing amount of nonacid polymer influencing hydrophobic properties of the material that may affect its catalytic performance in ETBE synthesis.

Texture. As Figure 3 demonstrates separate particles of polymer of irregular shape are clearly distinguishable for catalysts with low polymer loadings (1.5 and $1.7 \mathrm{wt} \%$ ). For composites with larger polymer loadings, polymer phase forms rough coating of inorganic phase.

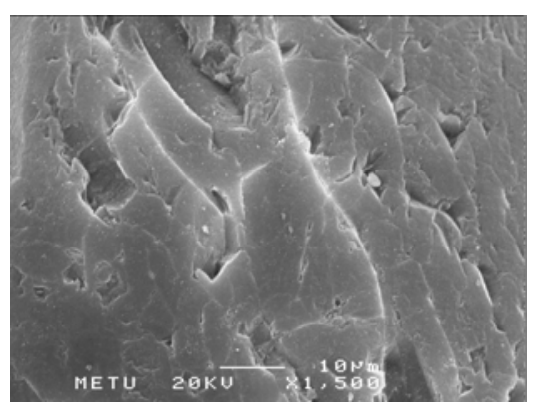

LR 3.5



LR 9.2

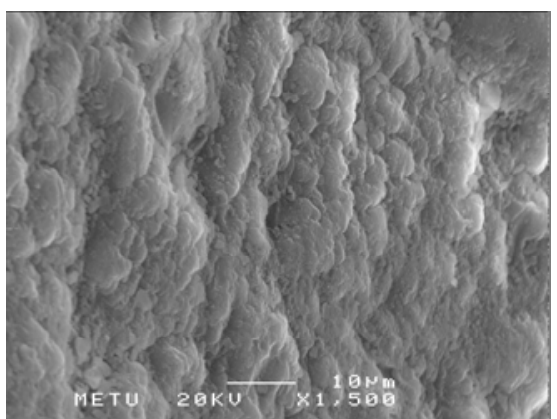

Fig. 3. SEM images of hybrid inorganic-organic acid materials 
Surface area. Varying the polymer loading leads to significant changes in surface area in studied materials as it follows from the data presented in Figure 4.

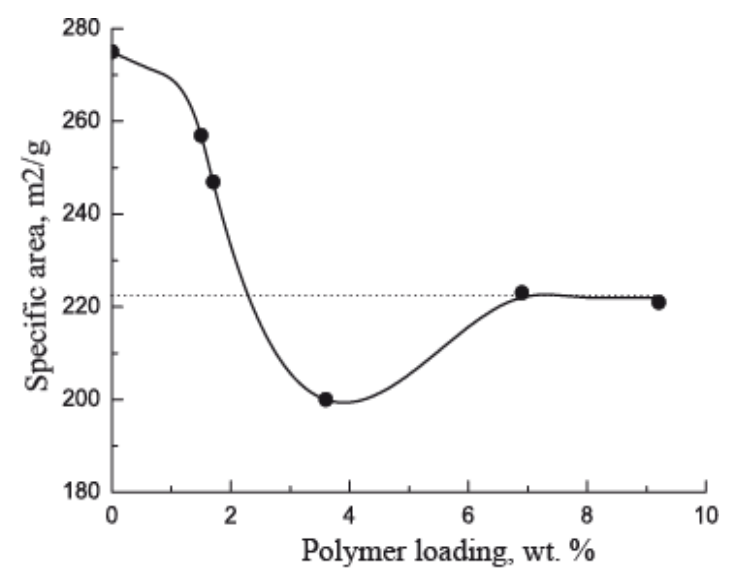

Fig. 4. Change in the surface area of LR samples with increase in polymer content

Increasing polymer loading up to $4 \mathrm{wt} \%$ decreases the surface area from 275 to $200 \mathrm{~m}^{2} / \mathrm{g}$ whereas further increasing polymer loading slightly increases its value up to $220 \mathrm{~m}^{2} / \mathrm{g}$. These changes in the surface area are in accord with the SEM data. Low covering of inorganic phase by polymer slightly reduces the surface area by blocking pores and smoothening its surface. At higher polymer loadings, the polymer phase starts forming rough surface by itself increasing surface area.

Thermal stability. Figure 5 gives results of thermogravimetric analysis for sample LR-9.2 that has the highest polymer loading among other catalysts.

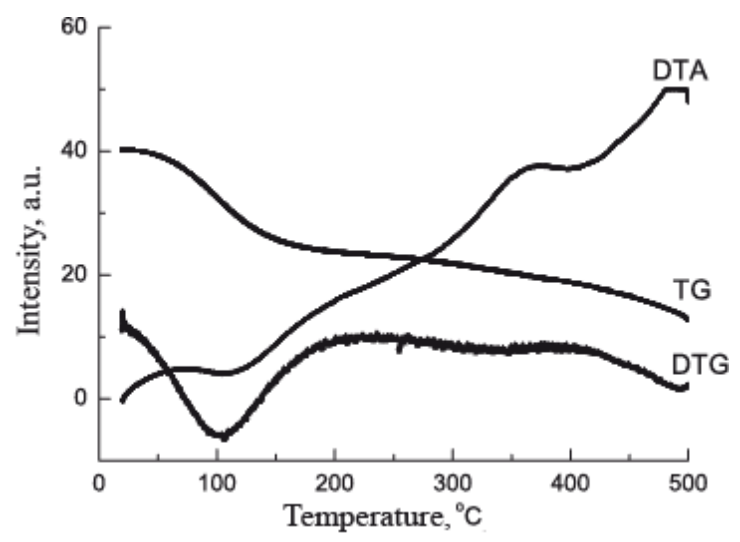

Fig. 5. Thermogram for sample LR-9.2

Increasing temperature results in a mass loss at the temperatures up to $500{ }^{\circ} \mathrm{C}$. DTA curve is characterized by two local maxima near 100 and $350{ }^{\circ} \mathrm{C}$. Endothermic effect at $100{ }^{\circ} \mathrm{C}$ is caused by loss of water. The wide exothermic peak with a maximum near $350{ }^{\circ} \mathrm{C}$ probably corresponds to decomposition of sulfonic acid groups [7, 10].

The results of thermogravimetry allow us to conclude that hybrid inorganic-organic acid materials are thermally stable at the temperatures at least up to $350{ }^{\circ} \mathrm{C}$. Therefore, their thermal stability is significantly higher than those of commercial sulfonic resins. It has been shown that at the temperatures above $150{ }^{\circ} \mathrm{C}$ thermal decomposition of sulfonic acid groups leads to a decrease in catalytic activity of such materials and to the formation of acidic wastes causing problems with corrosion of equipment [7]. Therefore, using hybrid inorganic-organic acid materials may significantly improve catalytic performance of acid catalysts used in industry.

Acid characteristics. Acidic properties of catalysts were evaluated from QETD data. Table gives corresponding characteristics for LR as total concentration of acid sites per $1 \mathrm{~g}$ of catalyst $\left(\mathrm{C}_{\mathrm{cat}}\right)$, total concentration of acid sites per $1 \mathrm{~g}$ of polymer phase in catalyst $\left(\mathrm{C}_{\mathrm{pl}}\right)$, and temperature of complete ammonia desorption.

Table. Acid properties of LR samples

\begin{tabular}{|c|c|c|c|}
\hline \multirow[b]{2}{*}{ Sample } & \multicolumn{2}{|c|}{ Acid capacity } & \multirow[b]{2}{*}{$\begin{array}{c}\mathbf{T}_{\text {des }} \\
\mathbf{N H}_{3}, \\
{ }^{\circ} \mathbf{C}\end{array}$} \\
\hline & $\begin{array}{c}\mathrm{C}_{\text {cat }} \\
\left(\mathrm{mmol} \mathrm{NH}_{3}\right) \\
\times \mathrm{g}_{\text {cat }}{ }^{-1} \\
\end{array}$ & $\begin{array}{c}\mathrm{C}_{\mathrm{pl}} \\
\left(\mathrm{mmol} \mathrm{NH}_{3}\right) \\
\times \mathrm{g}_{\mathrm{pl}}{ }^{-1} \\
\end{array}$ & \\
\hline LR-1.5 & 0.65 & 43.02 & 120 \\
\hline LR-1.7 & 0.66 & 38.71 & 150 \\
\hline LR-3.5 & 0.77 & 21.75 & $>150$ \\
\hline LR-6.9 & 0.68 & 9.87 & $>150$ \\
\hline LR-9.2 & 0.91 & 9.87 & $>150$ \\
\hline
\end{tabular}

The data presented in this Table show that $\mathrm{C}_{\text {cat }}$ does not change significantly with varying polymer loading exhibiting a slight tendency to increase with increasing polymer loading. Contrary, the value of $\mathrm{C}_{\mathrm{pl}}$ significantly decreases with increasing polymer loading. Taking into account that all sulfonic groups are located in polymer phase, we may conclude that polymer phase shows a tendency to be depleted by sulfonic groups with increasing polymer loading. At polymer loadings at $6-9 \mathrm{wt}$. \% concentration of acid sites becomes constant $\left(9.87\left(\mathrm{mmol} \mathrm{NH}_{3}\right) \times \mathrm{g}_{\mathrm{pl}}{ }^{-1}\right)$ and does not depend on polymer loading. At this value of polymer loading LR samples are characterized by a constancy of surface area.

LR with low content of polymeric phase (LR-1.5 and LR-1.7) show a complete desorption of ammonia at the temperatures below $150{ }^{\circ} \mathrm{C}$. Other samples hold ammonia at $150{ }^{\circ} \mathrm{C}$. The amount of remaining ammonia increases with increasing 
polymer loading. The temperature of ammonia desorption in quasi-equilibrium mode is directly related to the adsorption heat of ammonia [11]. Therefore, the temperature of ammonia complete desorption highlights a strength of acid sites. Increasing the temperature of ammonia complete desorption indicates an increase in the strength of acid sites. Therefore, strength of acid sites increases with increasing polymer loading in studied samples.

Comparing these results with SEM images we conclude that three-dimension layer of non-porous polymer is formed over inorganic phase at polymer loadings above 6-7 wt.\%. At these polymer loadings the increasing polymer content does not contribute to increase in the concentration of acid sites in loaded phase. However, increasing polymer loading in catalyst results in an increase in $\mathrm{C}_{\text {cat }}$ due to increasing the part of surface area that occupies the loaded phase.

Catalytic studies. The catalytic activity of LR in ETBE synthesis was investigated under both atmospheric $(0.1 \mathrm{MPa})$ and elevated pressure (1.0 MPa).

ETBE synthesis under atmospheric pressure. Catalytic studies of LR in the ETBE synthesis under atmospheric pressure show that only samples LR-3.5 and LR-9.2 exhibit appreciable activity at the temperatures below $100^{\circ} \mathrm{C}$. Fig. 6 shows a temperature dependence of $i s o$-butylene conversion for these catalysts. The selectivity of ETBE formation was found $100 \%$ in all cases.

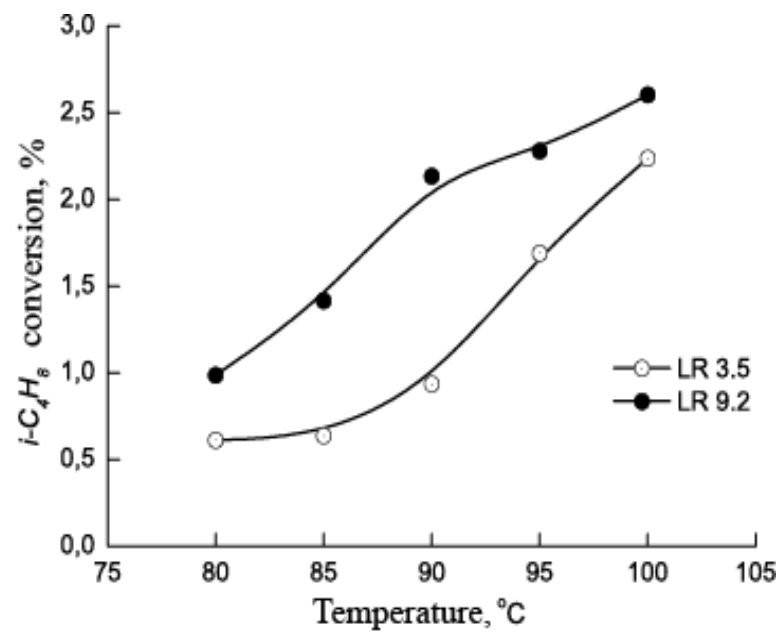

Fig. 6. Temperature dependences of $i-\mathrm{C}_{4} \mathrm{H}_{8}$ conversion in ETBE synthesis under atmospheric pressure over LR-3.5 and LR-9.2

Comparison of catalytic results with acidity of LR show that only catalysts with relatively high acid sites concentration $(0.91$ and 0.77 (mmol
$\left.\mathrm{NH}_{3}\right) \times \mathrm{g}_{\text {cat. }}{ }^{-1}$ ) are active. Moreover, we may conclude that increasing acid sites concentration increases catalytic activity of these materials.

ETBE synthesis under elevated pressure. Thermodynamics of ETBE synthesis from ethanol and iso-butylene supposes substantial effect of pressure on the process. Therefore, the activity of catalysts in ETBE synthesis under elevated pressure is substantially higher than that under atmospheric one.

Catalytic studies show that all of loaded resins are active in the ETBE synthesis under pressure. Figures 7 and 8 present the temperature dependence of iso-butylene conversion and the selectivity to ETBE respectively. The main byproduct of the process is tert-butyl alcohol as a result of interaction between iso-butylene and water introduced with azeotropic ethanol. For all studied catalysts the formation of di-iso-butylene or ethylene was not observed.

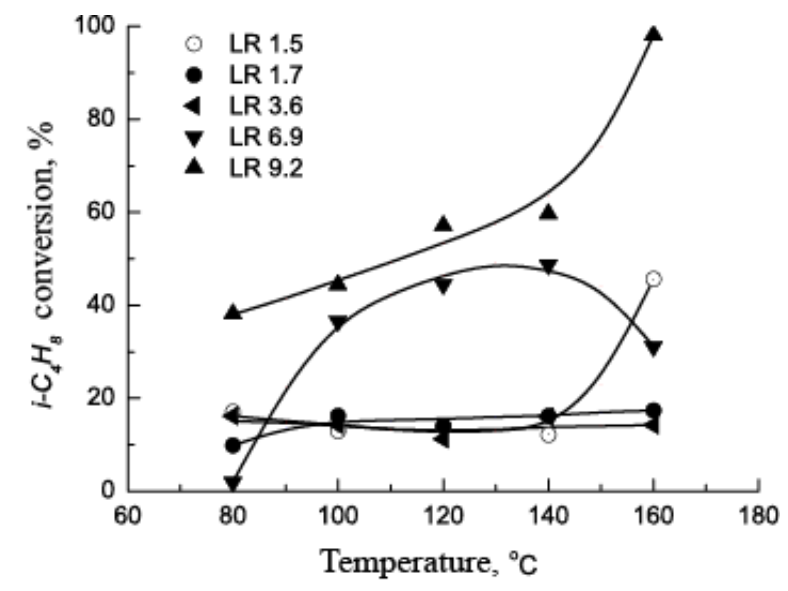

Fig. 7. Temperature dependences of $\mathrm{i}-\mathrm{C}_{4} \mathrm{H}_{8}$ conversion in ETBE synthesis under pressure over LR-X catalysts

The results presented in Figure 7 indicate that increasing content of polymer phase in the composite significantly increases the isobutylene conversion. For samples with low polymer loading (LR-1.5, LR-1.7 and LR-3.5) the iso-butylene conversion is less than $18 \%$ at the temperatures below $150{ }^{\circ} \mathrm{C}$. Contrary, samples with high polymer loadings (LR-6.9 and LR-9.2) show a significantly higher activity.

The content of the polymer phase in composites also significantly affects the selectivity (Fig. 8). Catalysts with low polymer loading LR-1.5, LR-1.7, and LR-3.5 have high ETBE selectivity. Increasing polymer loading strongly decreases the selectivity. 




Fig. 8. Temperature dependences of selectivity in ETBE synthesis under elevated pressure over LR-X catalysts

\section{CONCLUSIONS}

Our studies show that hybrid inorganic-organic acid materials have a promoted thermal stability comparing to commercial sulfonic acid ion exchange resins. Therefore, hybrid inorganicorganic acid materials can be effectively used in catalysis at the temperatures at least up to $350{ }^{\circ} \mathrm{C}$. Increasing the content of organic phase in catalysts above $6-7 \mathrm{wt} . \%$ results in formation of a solid polymer layer on the surface of inorganic support. Above these polymer loadings the surface area and concentration of acid sites per polymer loading does not change significantly.

Among synthesized hybrid inorganic-organic acid materials only LR-3.5 and LR-9.2 show appreciable activity at the temperatures below $100{ }^{\circ} \mathrm{C}$ with $100 \%$ of selectivity in ETBE synthesis under atmospheric pressure. In ETBE synthesis under elevated pressure all studied catalysts are active. However, selectivity is lower comparing to the synthesis under atmospheric pressure due to side reaction of tert-butanol formation. The obtained results indicate that only total concentration of acid sites affects activity of catalysts in ETBE synthesis under atmospheric pressure as well as under elevated one.

Comparison of SEM and QETD data shows that location of sulfonic groups inside polymeric layer results in increasing acid strength. As a result, tert-butanol formation in the synthesis of ETBE under elevated pressure reduces the selectivity. Therefore, the highest conversion of iso-butylene
LR 6.9 and LR 9.2 is accompanied by low ETBE productivity.

Our studies show that catalytic properties of thermally stable hybrid inorganic-organic acid materials can be easily adjusted by varying the content of polymeric phase. Namely, formation of isolated particles of polymer phase at low polymer loadings provides better sulfonation enhancing catalytic performance of these materials. At high polymer loadings the ETBE selectivity decreases for synthesis under elevated pressure due to increasing acid strength. These results indicate that hybrid inorganic-organic acid materials combine both thermal stability of inorganic phase and catalytic properties.

\section{ACKNOWLEDGEMENT}

This work is partially supported by the Ministry of Ukraine for Education and Science (Project No: M/21-2008) and TUBITAK (Project No: $107 \mathrm{M} 184)$ through a collaborative research project.

This paper was developed in collaboration with colleagues from Department of Chemical Engineering, Middle East Technical University, Ankara, Turkey, and Department of Chemical Engineering, Gazi University, Ankara, Turkey, especially with Professors T. Dogu and G. Dogu who assisted in obtaining some of the data described in this paper.

\section{REFERENCES}

1. Tanabe K., Hoelderich W.F. Industrial application of solid acid-base catalysts // Appl. Catal. A: Gen. - 1999. - V. 181. - P. 399-434.

2. Shin T., Rong Y., Harmon T., Suffet M. Evaluation of the impact of fuel hydrocarbons and oxygenates on groundwater resources // Environ. Sci. Technol. -2004. - V. 38. - P. 42-48.

3. Ogura T., Sakai Y., Miyoshi A. et al. Modeling of the oxidation of primary reference fuel in the presence of oxygenated octane improvers: ethyl tert-butyl ether and ethanol // Energy Fuels. - 2007. - V. 21. - P. 3233-3239.

4. Quitain A., Itoh H., Goto G. Industrial-scale simulation of proposed process for synthesizing ethyl tert-butyl ether from bioethanol // J. Chem. Eng. Jpn. - 1999. V. 32. - P. 539-543.

5. Parra D., Izquierdo J.F., Cunill F. et al. Catalytic activity and deactivation of acidic 1on-exchange resins in methyl tert-butyl ether 
liquid-phase synthesis // Ind. Eng. Chem. Res. - 1998. - V. 37. - P. 3575-3581.

6. Degirmenci L., Oktar N., Dogu G. Product distributions in ethyl tert-butyl ether synthesis over different solid acid catalysts // Ind. Eng. Chem. Res. - 2009. - V. 48. - P. 2566-2576.

7. Harmer M.A., Q. Sun Q. Solid acid catalysis using ion-exchange resins // Appl. Catal. A: Gen. - 2001. - V. 221. - P. 45-62.

8. Wight A.P., Davis M.E. Design and preparation of organic-1norganic hybrid catalysts // Chem. Rev. - 2002. - V. 102. P. 3589-3614.

9. Vlasenko N.V., Kochkin Yu.N., Topka A.V., Strizhak P.E. Liquid-phase synthesis of ethyl tert-butyl ether over acid cation-exchange inorganic-organic resins // Appl. Catal. A: Gen. - 2009. - V. 362. - P. 82-87.

10. Hart M., Fuller G., Brown D.R. et al. Sulfonated poly(styrene-co-divinylbenzene) ion-exchange resins: acidities and catalytic activities in aqueous reactions // J. Mol. Catal. A: Chem. - 2002. - V. 182-183. - P. 439-445.

11. Kapustin G.I., Brueva T.R. A simple method for determination of heat of ammonia adsorption on catalysts from thermodesorption data // Thermochim. Acta. - 2001. - V. 379. P. 71-75.

Received 14.11.2012, accepted 18.01.2013

\title{
Гібридні мінерально-органічні кислотні матеріали: фізико-хімічні та каталітичні характеристики в синтезі етил трет-бутилового ефіру
}

\section{Т.Г. Серебрій, Н.В. Власенко, Ю.М. Кочкін, П.Є. Стрижак}

\begin{abstract}
Інститут фізичної хімії ім. Л.В. Писаржевського Національної академії наук України
\end{abstract} пр. Науки, 31, Київ, 03039, Украӥна, tserebriy@rambler.ru

Досліджено фізико-хімічні та каталітичні характеристики гібридних органо-неорганічних кислотних матеріалів у процесі синтезу ЕТБЕ при атмосферному та підвищеному тиску. Ці матеріали - сульфовані композити співполімера стирол-дивінілбензол з діоксидом кремнію з різним (1.5-9.2 мас.\%) вмістом полімера LR. Виявлено, що LR є більш термостійкими, ніж промислові сульфокатіоніти. Зі збільшенням вмісту полімерної фази ї кислотність зменшується. При атмосферному тиску синтез ЕТБЕ відбувається зі $100 \%$ селективністю, проте потребує більш високої кислотності LR, ніж при підвищеному. При підвищеному тиску відбувається побічна реакиія утворення трет-бутанолу. LR з вмістом полімера $\geq 6.9$ мас. \% характеризується ниючою конверсією, проте більшою селективністю порівняно з $L R$ з вмістом полімера $<6.9$ мас. \%.

\section{Гибридные минерально-органические кислотные материалы: физико-химические и каталитические характеристики в синтезе этил трет-бутилового эфира}

\section{Т.Г. Серебрий, Н.В. Власенко, Ю.Н. Кочкин, П.Е. Стрижак}

Институт физической химии им. Л.В. Писаржевского Наџиональной академии наук Украины пр. Науки, 31, Киев, 03039, Украина, tserebriy@rambler.ru

Исследованы физико-химические и каталитические характеристики гибридных органонеорганических кислотных материалов в проиессе синтеза ЭТБЭ при атмосферном и повышенном давлении. Эти материаль - сульфированные композиты сополимера стирол-дивинилбензол с диоксидом кремния с различным (1.5-9.2 масс. \%) содержанием полимера LR. Обнаружено, что LR более термостабильны, чем промышленные сульфокатиониты. С ростом содержания полимерной фазы ее кислотность снижается. При атмосферном давлении синтез ЭТБЭ протекает со $100 \%$ селективностью, но требует более высокой кислотности $L R$, чем при повышенном. При повышенном давлении происходит побочная реакиия образования трет-бутанола. LR c содержанием полимера $\geq 6.9$ масс. \% характеризуется более низкой конверсией, но большей селективностью по сравнению с $L R$ c содержанием полимера $<6.9$ масс. \%. 